\title{
The Effectiveness of Figs Leaf (Ficus Carica L) and Rosy Periwinkle (Catharantus roseus) Decoction on SGOT and SGPT Levels of Male Wistar Strain Rats with Hepatitis Model
}

\author{
Debora Oktaviani ${ }^{1}$, Untung Sudharmono ${ }^{2}$ \\ ${ }^{1}$ Student of Nursing, Universitas Advent Indonesia \\ ${ }^{2}$ Faculty Of Nursing, Universitas Advent Indonesia \\ deboraoktaviani3@gmail.com
}

\begin{abstract}
Hepatitis is an inflammatory disease of liver cells that is contagious in the low category, the cause of it is bacteria, viruses, drugs and alcohol. The purpose of this study was to determine the effectiveness of boiled figs leaf (Ficus Carica L) and Rosy periwinkle (Catharantus roseus ) in reducing SGOT and SGPT levels. The subjects of this study were 30 male Wistar strain rats with age of 2-3 months, body weight 180-200 grams. Rats were divided into 3 groups; treatment groups, negative control groups and positive control groups. The treatment group and positive control group were induced paracetamol $120 \mathrm{mg} /$ day orally for 7 days. The treatment group was given 0.4 grams boiled figs leaf (Ficus Carica L) and 2.6 grams boiled rosy periwinkle (Catharantus roseus) it given as much as $3.6 \mathrm{cc} /$ day orally for 7 days. Data were analyzed with SPSS version 24, one way ANOVA test was performed to compare SGOT and SGPT levels. The results showed there were significant differences in SGOT levels between the treatment group, the positive control group, and the negative control group $(\mathrm{p}<0.05)$ and there was a significant difference in the SGPT value between the treatment group and the positive control group $(\mathrm{p}<0.05)$, while the negative control group and the treatment group there was no significant difference $(\mathrm{p}=0.75)$. The conclusion of this study was the water extraction of figs leaf (Ficus Carica L), Rosy periwinkle (Catharantus roseus) had an effect in decreasing the SGOT and SGPT values of male wistar strain rats induced by paracetamol.
\end{abstract}

Keywords: Paracetamol, SGOT SGPT, Rosy Periwinkle (Ficus Carica L), Figs (Catharantus roseus)

\section{INTRODUCTION}

Hepatitis is the 9th leading cause of death worldwide, both from the disease itself and complications from the hepatitis. It is estimated between $25-40 \%$ or equal to 350 million people worldwide suffer from hepatitis. In Indonesia, 1 out of 10 people suffer from hepatitis, 
which is estimated at 22.3 million people in Indonesia suffering hepatitis (Indonesian health policy, 2014).

In terms of biodiversity, Indonesia is in the second rank in the world after Brazil based on the diversity of flora and fauna. Globally, there are 30,000 types of flora can be found in Indonesia, for generations the Indonesian population from various ethnic groups has used 940 types of flora as herbal medicines. This number represents $90 \%$ of the herbal plants in the Asian (Muhtadi Haryoto, Tanti Azizah Sujono, 2015).

Herbal medicine is a kind of medicines made from plants, and herbs that can be easy or difficult to be found around us, herbal medicines are often also used for alternative medicines, or even drugs for the first treatment before the disease gets worse, and some herbal medicines can increase the immune system. (Sulfiyana, Herman, Rahma, 2019)

He development of modern medicines in Indonesia is rapidly developed, just as traditional medicines are developing into modern medicine packaging, herbal medicines have the advantage such as mild side effects, easy to find, and in one type of plant has several benefits. (Maripa Risni Baiq, 2019)

\section{LITERATURE REVIEW}

The color of the liver is brown, located in the upper right abdominal cavity under diaphragram, weighing 1000-1800 grams. The liver is an organ that functions to detoxify toxic substances in the body, in addition, the liver also functions to form a number of metabolic functions that function differently, producing proteins and hormones, clotting blood, controlling blood sugar and killing germs (Quoted from Dafriani 2019, P. 32)

One of the Laboratory examination of liver abnormalities is by measuring transaminase enzymes in assessing SGOT and SGPT activity that can show liver abnormalities in certain organs. (Rosida Asma, 2016). Damage in the liver can be caused by the use of high doses of Paracetamol, and if long-term use will cause necrosis of the liver (Wiryanti Ida, et al. 2017) Acute hepatitis is a disease caused by the HAV virus, spread through fecal-oral, entering the body when a person eats inside his food containing the HAV virus. Hepatitis is classified as a disease whose transmission is mild so that hepatitis patients can recover completely without leaving symptoms and cannot cause chronic infections. (Dalimunhe Aminah.2018)

Signs and symptoms that are commonly seen in someone who has acute hepatitis are changes in skin color throughout the body, fatigue easily during activities, decreased appetite, nausea, 
vomiting, thick tea-colored urine, and disorders of the liver especially in the digestive system. (Pratiwi Eka, et al, 2017)

An effective investigation to identify hepatitis is liver Ultasonogravi (USG) examination. The fasting time for performing an ultrasound liver is shorter adrift which is 4 hours. (Anshori M Dimas 2019, et al.) The results shown were "right and left lobe enlarged liver size, measured right lobe size that is $18.1 \mathrm{~cm}$ with a regular edge, while blood vessel screening with size and activity is still normal" (Anshori M Dimas 2019, et al p. 138)

Herbal medicine is the use of medicines made from plants, and herbs that are easy or hard to find around us, herbal medicines are often also used for alternative medicines, or even drugs for the first treatment before the disease gets worse, and some herbal medicines can increase immune system immune system. (Nurmalina, (Sulfiyana, Herman, Rahma, 2019)

The fig plant originates from the state of West Asia, which has been widely spread to and cultivated in a large scope in countries, Indonesia, Europe, North Africa, Spain, Turkey, and Italy, in the United States the culture is still in the small category. (Marpaung, AE and Hutabarat, RC. 2015)

Types of plants that we rarely know are useful for health, one of which is fig, because the fruit and leaves can be used for health, fig leaves contain antioxidants that help prevent, and reduce the exposure of free radicals that cause less effective work of cells in the body, figs function to fulfill daily needs because tin contains multivitamins and minerals. (Nisa, 2019)

\author{
"Kingdom : Plantae \\ Subkingdom : Tracheobionta \\ Super divisi : Spermatophyta \\ Division : Magnoliophyta \\ Class : Magnoliopsid \\ Subkelas : Dilleniidae \\ Order : Rosales \\ Family : Moraceae \\ Genus : Ficus \\ Species : Ficus carica L. \\ "Materia Medika, 2014"
}

Rosy periwinkle originating from the country of Madagascar, has spread widely into the tropics. Latin name of it is Catharanthus roseus. In Indonesia, it is known or commonly used as an ornamental plant. In each city or name has its own nickname. The city of Sulawesi 
called it Sindapar call, in Bandung called as kembang tembaga, in the area of Central Java called as tapak dara, in Malaysia known as sari china or pokok ros pantai, in the Philippines as Tsitsirika, in the Vietnamese as hoa dang. In China known as chang chun hua, in the Netherlands as soldaten bloem, and in the United Kingdom as rose periwinkle. (Pom Agency. 2019)

\author{
Kingdom : Plantae \\ Division : Magnoliophyta \\ Class : Magnoliopsida \\ Order : Gentianales \\ Family : Apocynaceae \\ Genus : Catharanthus \\ Species : Catharanthus roseus (L.) G. Don \\ (Satyarsa Agung BS. 2019)
}

Rosy periwinkle has flavonoids which function as antioxidants. Antioxidants function to protect the body from exposure to free radicals that slowly damage the body. Putri Risa Rahma, Judge .R. F, Sustenance Sri (2017)

\title{
METHODS
}

This is a laboratory research. The object of this study is 30 male Wistar strain rats with a body weight of 180-200 grams, with 2-3 months of age divided into 3 groups. Group 1 was negative control group (no therapy was given and the liver was not damaged), group 2 was positive control group (rat liver was damaged with $120 \mathrm{mg}$ paracetamol without treatment), group 3 was treated group (rat liver was damaged with $120 \mathrm{mg}$ paracetamol and was given tin leaf extract and herd of $3.6 \mathrm{cc}$ po / day for 7 days. All groups were adapted for 7 days With the method of 12 hours in the morning and 12 hours at night, all groups were given food and drink as usual After 7 days it was expected that the body weight of the mouse $\pm 10 \%$ from the standard.

Rosy periwingkle (Catharanthus roseus L) taken from West Bandung, Parongpong. While the figs (Ficus Carica) are taken from Cimenyan, the part of rosy pereiwinkle (Catharanthus roseus L) that used are roots, stems, leaves and flowers. the plant washed till clean, then cut into small pieces. After being cut it dried under the leaf drying for 1 week, the part of Figs plant that is used is juts the leves, the leaves are washed until clean, cuted into small pieces and then dried for 4 days. Rosy pereiwnkle (Catharanthus roseus L) were used as much as 2.6 
grams, tin leaves of Ficus Carica were used as much as 0.4 grams then boiled by water from $300 \mathrm{cc}$ to $100 \mathrm{cc}$ for 9 minutes 30 minutes to get maximum mixing.

Group 2 (positive controle group) was induced by paraetamol as much as $120 \mathrm{mg} /$ oral for 7 days, this process couse the damage in the liver of male wistar rats so the level of SGTO and SGTP increase. To know the level of SGTO and SGTP serum, the tail of the rats was cute to release the blood out.

\section{RESULTS}

Data were collected using SPSS version 24 with One Way ANNOVA to find out the levels of SGOT and SGPT before and after being damaged after induced with $120 \mathrm{mg}$ paracetamol, and also the data before and after the water treatment of fig leaves (Ficus Carica) rosy periwinkle (catharanthus roseus $L$ ) as much as $3.6 \mathrm{cc}$ for 7 days.

SGOT (Serum Glutamic Oxaloacetic Transminase) is an enzyme in the body not only in the liver, SGOT will be detected if abnormalities occur such as necrosis or trauma to a tissue. SGOT can be used as a comparison of the extent of damage to the liver, if the liver is damaged, the SGOT enzyme will be released through the blood. (Harianto Wulandari Eka Christine, et al, 2018)

Serum Glutamic Pyruvic Transaminase (SGPT) is one indicator to determine the level of liver damage. The concentration of the Enzyme will increase when the liver is damaged / abnormalities such as hepatitis. SGPT enzymes will be released through the circulation of blood ( Harianto Wulandari Eka Christine, et al, 2018)

Water therapy of fig leaves and rosy periwinkle decoction as much as $3.6 \mathrm{cc}$ is induced to male Wistar galus rats with acute hepatitis model. The results of the study as follows:

Table 1. the result SGTO level before the therapy of fig leave ( Ficus Carica) and rosy periwinkle (Catharanthus roseus $L$ ) decoction to the rate with the liver damaged cause by paracetamol $120 \mathrm{mg}$

\begin{tabular}{|l|l|l|l|l|l|}
\hline $\begin{array}{c}\text { Dependent } \\
\text { Variable }\end{array}$ & (I) group & \multicolumn{1}{|c|}{$(\mathrm{J})$ group } & $\begin{array}{c}\text { Mean } \\
\text { Difference (I-J) }\end{array}$ & Std. Error & Sig. \\
\hline \multirow{3}{*}{ sgot_pre } & 1.00 & 2.00 & $-211.81000^{*}$ & 5.13555 & .000 \\
\cline { 2 - 6 } & 3.00 & $-223.82000^{*}$ & 5.13555 & .000 \\
\cline { 2 - 6 } & 2.00 & 1.00 & $211.81000^{*}$ & 5.13555 & .000 \\
\cline { 2 - 6 } & 3.00 & -12.01000 & 5.13555 & .067 \\
\cline { 2 - 6 } & \multirow{2}{*}{3.00} & 1.00 & $223.82000^{*}$ & 5.13555 & .000 \\
\cline { 2 - 6 } & 2.00 & 12.01000 & 5.13555 & .067 \\
\hline
\end{tabular}


From the above data, group 1 (negative control) was only given normal food and drink, compared to group 2 (positive control) the liver of the rat was damaged with $120 \mathrm{mg}$ of paracetamol and group 3 (the treatment of) the liver of the rat was also damanged with 120 mg of paracetamol. Group 1 (negative control) compared to group 2 (positive control) shows a significant difference in SGOT levels $\mathrm{p}(<0.05)$ because the liver of the group 2 (positive control) had been damaged with $120 \mathrm{mg}$ of paracetamol orally, compared with group 2 (positive control) and group 3 (treated) the liver of rats were destroyed with paracetamol $120 \mathrm{mg}$ and it show no significant results $\mathrm{p}(=0.067)$. The use of paracetamol with high doses and in long period of time will cause hepatocyte necrosis which is marked by an increase in SGOT and SGPT levels. this was proven by (Wahid Rahman Abdul, Safwan's 2017) research on the Antioxidant Effects of Ethanol Extract of Aloes (Aquilaria malaccensis L.) Leaves in Sprague Dawley Male Rats Induced by Paracetamol

Table 2. the result SGTO level after the therapy of fig leave ( Ficus Carica) and rosy periwinkle (Catharanthus roseus $L$ ) decoction to the rate with the liver damaged cause by paracetamol $120 \mathrm{mg}$

\begin{tabular}{|c|l|l|l|l|l|}
\hline $\begin{array}{c}\text { Dependent } \\
\text { Variable }\end{array}$ & (I) group & (J) group & $\begin{array}{c}\text { Mean } \\
\text { Difference (I-J) }\end{array}$ & Std. Error & Sig. \\
\hline \multirow{2}{*}{ sgot_pre } & \multirow{2}{*}{1.00} & 2.00 & $-963.23000^{*}$ & 15.21498 & .000 \\
\cline { 2 - 6 } & 2.00 & $-76.58000^{*}$ & 15.21498 & .000 \\
\cline { 2 - 6 } & \multirow{2}{*}{2.00} & 3.00 & $963.23000^{*}$ & 15.21498 & .000 \\
\cline { 2 - 6 } & \multirow{2}{*}{3.00} & 1.00 & $766.65000^{*}$ & 15.21498 & .000 \\
\cline { 2 - 6 } & 2.00 & $-886.65000^{*}$ & 15.21498 & .000 \\
\hline
\end{tabular}

From the above data, it was found that group 1 (negative control) was only given normal food and drink compared to group 2 (positive control) which suffer liver demage due to the unduction of paracetamol $120 \mathrm{mg}$ shows a significant difference in $\mathrm{p}(<0.05)$. Group 1 (negative control) compared with group 3 (treatment) also shows a significant difference $\mathrm{p}$ $(<0.05)$ because in group 3 (treatment) of the liver of the rats had been destroyed with $120 \mathrm{mg}$ paracetamol and then given the water therapy of fogs eave (Ficus Carica) and rosy periwinkle (Catharanthus roseus $L$ ) as much as $3.6 \mathrm{cc}$ for 7 days orally. Due to the short duration of induction, SGOT levels showed significant differences. p $(<0.05)$. Both liver of Group 2 (negative control) and group 3 (treatment) were damaged by paracetamol 120mg, but groupd three (treatmen group) get the water therapy of fogs leave Ficus Carica and Catharanthus roseus $L$ decoction as much as 3.6/ days. Paracetamol is safe to use at normal 
doses, if it used excessively it will cause hepatoxicity. Hepatoxicity is liver damage caused by overdose of paracetamol. Fitri Nadia Silvani, Asep Sukohar, Waluyo Rudiyanto (2019)

Table 3. the result SGTP level before the therapy of fig leave ( Ficus Carica) and rosy periwinkle (Catharanthus roseus $L$ ) decoction to the rate with the liver damaged cause by paracetamol $120 \mathrm{mg}$

\begin{tabular}{|c|l|l|l|l|l|}
\hline $\begin{array}{c}\text { Dependent } \\
\text { Variable }\end{array}$ & (I) group & (J) group & $\begin{array}{c}\text { Mean } \\
\text { Difference (I-J) }\end{array}$ & Std. Error & Sig. \\
\hline \multirow{2}{*}{ sgot_pre } & 1.00 & 2.00 & $-135.66000^{*}$ & 4.44647 & .000 \\
\cline { 2 - 6 } & 3.00 & $-145.25000^{*}$ & 4.44647 & .000 \\
\cline { 2 - 6 } & 2.00 & 1.00 & $135.66000^{*}$ & 4.44647 & .000 \\
\cline { 2 - 6 } & 3.00 & -9.59000 & 4.44647 & .097 \\
\cline { 2 - 6 } & \multirow{2}{*}{3.00} & 1.00 & $145.25000^{*}$ & 4.44647 & .000 \\
\cline { 2 - 6 } & 2.00 & 9.59000 & 4.44647 & .097 \\
\hline
\end{tabular}

From the above data, group 1 (negative control) was only given normal food and drink compared to group 2 (positive control) which the liver of the rat was damaged with 120 $\mathrm{mg}$ paracetamol and group 3 (treatment) which the liver was also damaged with $120 \mathrm{mg}$ of paracetamol for 7 days and the SGPT level was significantly different $(<0.05)$ because the liver of group 2 (negative control) was damaged with $120 \mathrm{mg}$ of paracetamol. and group 1 (negative control) were only given normal food and drink. This is supported by a comparison of group 2 (positive control) and group 3 (treatment) whose liver was equally damaged by $120 \mathrm{mg}$ of paracetamol, there was an insignificant difference in $\mathrm{p}(=0.97)$. Hepatoxicity is a disease caused by an overdose of paractemol. Sukohar, Soleha, Hafizfadillah (2019)

Table 4. the result SGTP level before the therapy of fig leave ( Ficus Carica) and rosy periwinkle (Catharanthus roseus $L$ ) decoction to the rate with the liver damaged cause by paracetamol $120 \mathrm{mg}$

\begin{tabular}{|l|l|l|l|l|l|}
\hline $\begin{array}{c}\text { Dependent } \\
\text { Variable }\end{array}$ & (I) group & (J) group & $\begin{array}{c}\text { Mean Difference } \\
(\mathrm{I}-\mathrm{J})\end{array}$ & Std. Error & Sig. \\
\hline \multirow{2}{*}{ sgot_pre } & 1.00 & 2.00 & $-945.33000^{*}$ & 17.94796 & .000 \\
\cline { 2 - 6 } & 2.00 & 41.05000 & 17.94796 & .075 \\
\cline { 2 - 6 } & 2.00 & 1.00 & $945.33000^{*}$ & 17.94796 & .000 \\
\cline { 2 - 6 } & 3.00 & 1.00 & $986.38000^{*}$ & 17.94796 & .000 \\
\cline { 2 - 6 } & & 2.00 & -41.05000 & 17.94796 & .075 \\
\hline
\end{tabular}


From the data above, group 1 (negative control) which only given normal food and drink compared to group 2 (positive control) which the liver was damaged with $120 \mathrm{mg}$ of paracetamol shows a significant results $(<0.05)$ because the liver in group 2 (negative control) was damaged with $120 \mathrm{mg}$ paracetamol. Group 1 (negative control) compared to group 3 (treatment) show insignificant condition $(=0.075)$ because group 3 (treatment) which the liver was damaged with $120 \mathrm{mg}$ of paracetamol and then given $3.6 \mathrm{cc}$ of figs and rosy periwinkle decoction therapy as much as $3.6 \mathrm{cc}$ that has an effect of reducing SGPT levels. Group 2 (negative control) compared to group 3 (treatment) shows a significant difference $(<0.05)$ because the liver of the group 2 (negative control) was damaged with $120 \mathrm{mg}$ of paracetamol, while the liver of group 3 (treatment) was also damaged with $120 \mathrm{mg}$ of paracetamol but this group get a water teraphy of figs and rosy periwinkle decoction as much as $3.6 \mathrm{cc}$ for 7 days.

\section{DISCUSSION}

Based on the data above, it can be concluded that the levels of SGOT in group 1 (negative control), group 2 (positive control) and group 3 (treatment) shows a significant difference. While SGPT levels in group 1 (negative control), group 2 (positive control) and group 3 (treatment) were not significantly different.

\section{Conclusion}

On the laboratory examination of $120 \mathrm{mg}$ administration of Paracetamol in male wistar starin rats with acute hepatitis model for 7 days can damage or increase the levels of SGOT and SGPT.

Fig leaves and Rosi periwckle dection that given for 7 days has the effect of reducing the SGOT and SGPT levels because the decoction of 0.4 grams of figs leaves and 2.6 grams rosi periwinkle that boiled in 300c water to $100 \mathrm{cc}$ for 9 minutes 30 seconds is effective in reducing levels SGOT and SGPT in male wistar strain rate with acute hepatitis model.

\section{REFERENCES}

Agung BS Satyarsa. (2019). Potential Effects of Alkaloid vindolicine Substances in Tapak Dara Leafs (Catharanthus roseus (L.) G. Don) in Reducing Blood Glucose Levels Journal of Medicine and Health Potential Effects of Alkaloid, 2(4), 1009-1019 
Anshori M Dimas, Heru N, Sari G, Istiqomah H. (2019) Pemeriksaan Ultrasonografi Hepar menjadi Pemeriksaan Penunjang yang Tepat untuk Diagnosa Hepatitis, 6(2), 131139

Badan Pom (2019) http://mesotsmkos.pom.go.id/news/tapak-dara- catharanthus-roseus-l-don

Dafriani. Putri. (2019). Buku Ajar Anatomi \&Fisiologi untuk Mahasiswa Kesehatan

Dalimunhe Aminah. (2018). Aktivitas Hepatoprotektor Ekstrak Etanol Kulit Bawang Merah (Allium cepa L. Corium) Terhadap Mencit Jantan yang Diinduksi Parasetamol ISSN no 2623-0542, 2-6

Harianto Wulandari Eka Christine, Hasian Ta, Widyaningsih D. Tr. (2018). Uji Efektivitas Sifat Hepatoprotektor Ekstrak Bawang Lanang pada Tikus Wistar Jantan yang Diinduksi Parasetamol. Jurnal Pangan dan Agroindustri, 6(4), 1-10

(“Indonesia Negara Endemis Tinggi Hepatitis” 2014)

Kartika Asri Anggraeni. (2019). Pengaruh Pemberian Ekstrak Buah Tin (ficus carica L) terhadap Gambaran Histopologi Sel b Pancreas Tikus Putih Jantan (rattus novergicus) Strain Wistar yang Diinduksi Aloksan

Marpaung, AE dan Hutabarat, RC. (2015). Respons Jenis Perangsang Tumbuh Berbahan Alami dan Asal Setek Batang Terhadap Pertumbuhan Bibit Tin (Ficus carica L.) (The Response of Natural Growing Stimulant Materials and Stem Cutting Origin to the Growth of Fig Seedling). J.Hart, 25(1), 37-41

Muhtadi Haryoto, Tanti Azizah Sujono .(2015). Uji Toksisitas Akut dari Ekstrak Kulit Buah Rambutan (Nephelium lappaceum 1.) yang Berpotensi sebagai Obat Herbal Antidiabetes. Prosiding University Research Colloqium. Surakarta, Indonesia: LPPM UMS. ISSN 2407-9189

Nadia Silvani Fitri, Sukohar. A, Rudiyanto. W, (2019) Pengaruh Ekstrak Etanol Belimbing Wuluh (Averrhoa bilimbi Linn) Sebagai Antioksidan terhadap Histopatologi Hepar Tikus Galur Sprague dawley yang Diinduksi Parasetamol. Medical Journal of Lampung University, 8(1).

Nisa (2015) Manfaat daun tin dan tapak dan tapak dara bagi kesehatan-tubuh-bantu-obatipenyakit https://hot.liputan6.com/read/4036585/manfaat-buah-tin-dan-daunnyabagi.

Putri Risa Rahma, Hakim .R. F, Rezeki Sri (2017) Pengaruh Ekstrak Daun Tapak Dara (Catharanthus Roseus) Terhadap Jumlah Fibroblas Pada Proses Penyembuhan Luka di Mukosa Oral. Journal Caninus Dntistry, 2(1), 20-30.

Pratiwi Eka, Soekarso T, Adam K, Setiawaty V (2017) Identifikasi Virus Hepatitis A pada Sindrom Penyakit Kuning Akut di Beberapa Provinsi di Indonesia Tahun 2013. Global Medical \& Health Communcation, 5(3), 200-205 
Rahman Abdul Wahid, Safwan. (2019). Efek Antioksidan Ekstrak Etanol Daun Gaharu (Aquilaria malaccensis L.) pada Tikus Jantan Galur Sprague Dawley yang Diinduksi Paracetamol (Kajian Aktivitas Enzim Katalase, SGOT dan SGPT). PHARMAUHO: Jurnal Farmasi, Sains dan Kesehatan. ISSN: 2442-9791

Rosida Azma. (2016). pemeriksaan laboratorium penyakit hati. Banjarmasin 12 (1), 123-131

Sitepu N. B, Masrah Pengaruh Pemberian Ekstrak Etanol Herbal Sembukan. (2018). (paederia scandens) terhadap Aktivitas Enzim Alanine transaminase (alt) dan Aspartate Transaminase (ast) pada Mencit Jantan (musmusculus) yang Diinduksi Parasetamol Jurnal Saintika, 18(1), 12 - 1

Sukohar Asep, Soleha. T .U, Hafizfadillah. D. (2019). Pengaruh Ekstrak Etanol Belimbing Wuluh (Averrhoa Bilimbi Linn) Sebagai Antioksidan terhadap Kadar SGPT (Serum Glutamic Pyruvate Transaminase) serta SGOT (Serum Glutamic Oxaloacetic Transaminase) Tikus Galur Sprague Dawley yang Diinduksi Parasetamol. JK Unila, $3(1), 123-128$

Wiryanti Ida, Kunthia R. A, Sinaga E. (2017). Efek Hepatoprotektif Ekstrak Rimpang Bangle Hantu(Zingiber ottensii) pada Tikus Terinduksi Parasetamol. Prosiding Seminar Nasional Pendidikan Biologi Unsyiah 2017, 2(1), 178-185 . 